
cultures

Les cahiers de l'Acedle

17-1 | 2020

RDLC revue en lutte

\title{
Sciences en danger
}

Collectif Anonyme et Camille Noûs

\section{(2) OpenEdition \\ Journals}

Édition électronique

URL : http://journals.openedition.org/rdlc/7264

DOI : $10.4000 /$ rdlc.7264

ISSN : 1958-5772

Éditeur

ACEDLE

\section{Référence électronique}

Collectif Anonyme et Camille Noûs, « Sciences en danger », Recherches en didactique des langues et des cultures [En ligne], 17-1 | 2020, mis en ligne le 06 avril 2020, consulté le 18 avril 2020. URL : http:// journals.openedition.org/rdlc/7264; DOI : https://doi.org/10.4000/rdlc.7264

Ce document a été généré automatiquement le 18 avril 2020

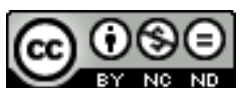

Recherches en didactique des langues et des cultures is licensed under a Creative Commons AttributionNonCommercial-NoDerivatives 4.0 International License 


\section{Sciences en danger}

\section{Collectif Anonyme et Camille Noûs}

RÉSUMÉS

Article vide

INDEX

Mots-clés : revues en lutte, université ouverte, sciences en danger, RDLC 